\title{
Salinity Tolerance of Larval Rapana venosa: Implications for Dispersal and Establishment of an Invading Predatory Gastropod on the North American Atlantic Coast
}

\author{
Roger L. Mann \\ Virginia Institute of Marine Science \\ Juliana M. Harding \\ Virginia Institute of Marine Science
}

Follow this and additional works at: https://scholarworks.wm.edu/vimsarticles

Part of the Aquaculture and Fisheries Commons, and the Ecology and Evolutionary Biology Commons

\section{Recommended Citation}

Mann, Roger L. and Harding, Juliana M., "Salinity Tolerance of Larval Rapana venosa: Implications for Dispersal and Establishment of an Invading Predatory Gastropod on the North American Atlantic Coast" (2003). VIMS Articles. 1688.

https://scholarworks.wm.edu/vimsarticles/1688

This Article is brought to you for free and open access by the Virginia Institute of Marine Science at W\&M ScholarWorks. It has been accepted for inclusion in VIMS Articles by an authorized administrator of W\&M ScholarWorks. For more information, please contact scholarworks@wm.edu. 


\title{
Salinity Tolerance of Larval Rapana venosa: Implications for Dispersal and Establishment of an Invading Predatory Gastropod on the North American Atlantic Coast
}

\author{
ROGER MANN* AND JULIANA M. HARDING \\ Department of Fisheries Science, Virginia Institute of Marine Science, College of William and Mary, \\ Gloucester Point, Virginia 23062
}

\begin{abstract}
The lack of quantitative data on the environmental tolerances of the early life-history stages of invading species hinders estimation of their dispersal rates and establishment ranges in receptor environments. We present data on salinity tolerance for all stages of the ontogenetic larval development of the invading predatory gastropod Rapana $v e n o s a$, and we propose that salinity tolerance is the dominant response controlling the potential dispersal (=invasion) range of the species into the estuaries of the Atlantic coast of the United States from the current invading epicenter in the southern Chesapeake Bay. All larval stages exhibit 48-h tolerance to salinities as low as $15 \mathrm{ppt}$ with minimal mortality. Below this salinity, survival grades to lower values. Percentage survival of $R$. venosa veligers was significantly less at $7 \mathrm{ppt}$ than at any other salinity. There were no differences in percentage survival at salinities greater than 16 ppt. We predict that the counterclockwise, gyre-like circulation within the Chesapeake Bay will initially distribute larvae northward along the western side of the DelMarVa peninsula, and eventually to the lower sections of all major subestuaries of the western shore of the Bay. Given the observed salinity tolerances and the potential for dispersal of planktonic larvae by coastal currents, establishment of this animal over a period of decades from Cape Cod to Cape Hatteras is a high probability.
\end{abstract}

\section{Introduction}

The Norway/United Nations Conference on Alien Species considers alien invasive species as the second most

Received 2 July 2002; accepted 4 November 2002.

* To whom correspondence should be addressed.E-mail: rmann@ vims.edu important threat, after habitat destruction, to indigenous biodiversity (Sandlund et al., 1999). Despite the widespread historical records of both intentional and accidental introductions of fauna and flora to novel environments beyond their natural ranges, the ability to predict establishment and subsequent range expansion in the receptor environment remains poor for both terrestrial and aquatic systems (Williamson, 1996; Sandlund et al., 1999). This should not be surprising given the difficulty of describing the niche (sensu Hutchinson, 1979) of the invader in its native range, let alone in a novel, receptor environment. In examining the success of introductions, Vermeij (1996) poses the question "What factors prevent populations from spreading beyond their geographical limits?" He then proffers one possible answer-that physiological tolerances are evolutionarily conservative, resulting in ranges being set by physical circumstances that prevent reproduction or survival. Thus physiological tolerances probably set the maximum spatial limits of the species, again to quote Vermeij (1996), by "the presence of competitors, predators, or disease organisms, or the absence of a critical host, food, or symbiotic species." The gravity of the impact of invasions on current biodiversity dictates the need to move beyond our current, often anecdotal, understanding of range limitation so that we can predict the effects of invasions and develop suitable control measures.

Marine and estuarine molluscs are well represented in the fauna that have been introduced over historical time to new locations where they have become established and, in some instances, dominant factors in shaping the extant communities (Carlton, 1999). The western Pacific Ocean has emerged as a donor region for invading species that have 
become established in the eastern Pacific and Atlantic Oceans, the Mediterranean and Black Seas, and parts of Australasia. Invading western Pacific gastropods are mostly small, their dispersal being facilitated as a component of surface fouling communities or within rock ballast. Invasions of large predatory gastropods have, by comparison, been modest. Their generally infaunal habit and large adult size serves them poorly in maintaining attachment to exposed fouling communities, and their late maturation limits recruitment to exposed and disturbed fouling communities in transit. The recent emergence of ballast water as a vector in effecting invasions (Carlton, 1996, 1999) has, however, expanded the potentially invading gastropod fauna to include species characterized by a life history that combines large adult size with planktonic larval dispersal phases. A prime example of this newly facilitated invader is the predatory gastropod Rapana venosa Valenciennes 1846. This species was formerly classified in the subclass Prosobranchia, order Neogastropoda, but is currently placed in the subclass Orthogastropoda, family Muricidae, subfamily Rapaninae (=subfamily Thaididae; see Kool, 1993). Rapana venosa, commonly termed the rapa whelk, is native to the Sea of Japan, the Yellow Sea, the Bohai Sea, the East China Sea to Taiwan in the south, and Peter the Great Bay off Vladivostok in the north (Golikov, 1967; Lai and Pan, 1980; Tsi et al., 1983). The introduction of $R$. venosa to the Novorossiysky Bay in the Black Sea in the 1940s, probably as a species associated with oysters transported from the Orient, is described by Drapkin (1963). Limited records of occurrence of $R$. venosa have also been made on the Pacific coast of Canada and in Willapa Bay, Washington, in the United States (Hanna, 1966, page 47). These introductions were probably associated with commercial importation of oysters from Japan during the same time frame that rapa whelks were first observed on the Pacific Coast. $R$. venosa has not become established on the Pacific coast of North America. In sharp contrast, the species has become established in the Black Sea with significant damage to native benthos (e.g., bivalves; notably Ostrea edulis, Pecten ponticus, and Mytilus galloprovincialis [Zolotarev, 1996], and its subsequent invasion of the Aegean, Adriatic, and Mediterranean Seas has been well documented (Drapkin, 1963; Ghisotti, 1971, 1974; Mel, 1976; Terreni, 1980; Cucaz, 1983; Chukchin, 1984; Rinaldi, 1985; Marinov, 1990; Koutsoubas and Voultsiadou-Koukoura, 1990; Bombace $e t$ al., 1994; Zolotarev, 1996).

Recent transoceanic invasions by $R$. venosa, probably facilitated by transport of larval stages in ballast water, have resulted in occurrence of the species in the Chesapeake Bay on the Mid-Atlantic coast of the United States (Harding and Mann, 1999; Mann and Harding, 2000), on the Brittany coast of France (Dr. Philippe Goulletquer, IFREMER, pers. comm., 1999), and in the Rio del Plata between Uruguay and Argentina (Pastorino et al., 2000; F. Scarabino, Na- tional Museum of Natural History and National Institute of Fisheries, Uruguay, pers. comm. 2000). Furthermore, regions formerly insulated from contact with this predatory species must now be considered susceptible to continued exposure to it in ballast water. The ecological and economic impacts associated with the arrival and possible establishment of $R$. venosa in the southern Chesapeake Bay has stimulated a program to quantitatively describe the niche of the species in this new location. Such a description will be helpful in predicting the potential of the species to become established within the Chesapeake Bay and further afield along the Atlantic coast. This report describes the response of pelagic larval stages of $R$. venosa to variations in salinity. Because salinity tolerance is an evolutionarily conservative feature of the species, we argue that it sets a maximal range on the distribution of the organism in this new location.

\section{Materials and Methods}

Individuals of Rapana venosa mature at 1-2 years of age, are dioecious as adults, and display mating activity all year in laboratory populations (Harding and Mann, unpubl. data). Eggs are laid in masses characteristic of the genus Rapana (see Chung et al., 1993; Morton, 1994; Harding and Mann, 1999). Adult broodstock for the current study were collected as by-catch of commercial crab and clam fisheries in the Hampton Roads region of the Chesapeake Bay (Fig. 1 ) in the spring of 2000. These animals were maintained at the Gloucester Point laboratory of the Virginia Institute of Marine Science, on the York River, Virginia, until the initiation of the larval studies. They were held in 800-1 tanks supplied with flowing seawater from the York River. The water was kept at ambient temperature and salinity (20-26 ${ }^{\circ} \mathrm{C}$ and 18-21 ppt respectively for the experimental period), and the animals were fed ad libitum with clams, Mercenaria mercenaria, as prey. Egg masses for the current study were laid during the months of June through September.

The egg masses, which typically were attached to the walls of the holding tank, were collected within $24 \mathrm{~h}$ of deposition. Individual egg masses were maintained in 11 of static filtered seawater ( 18 to $21 \mathrm{ppt}$ ) at 20 to $26^{\circ} \mathrm{C}$ and $10 \mathrm{~h}$ light/14 h dark conditions through hatching. After hatching or release of veliger larvae from egg cases within an egg mass, the larvae were maintained in aerated filtered seawater under the same conditions as the egg masses and at densities of about 500 veligers per liter of seawater. Veligers were fed a mixed diet of Pseudoisochrysis paradoxa, Chaetocerus gracilis, and Tetrasalmis sp. every other day.

Larval cultures designated for experiments on salinity tolerance, except for trials on newly hatched larvae, were maintained at initial experimental salinities for $48 \mathrm{~h}$ before an experiment. One hour before the beginning of an experiment, the cultures were sieved through an $80-\mu \mathrm{m}$ mesh to condense the larvae into a small volume of water. A 1-ml 


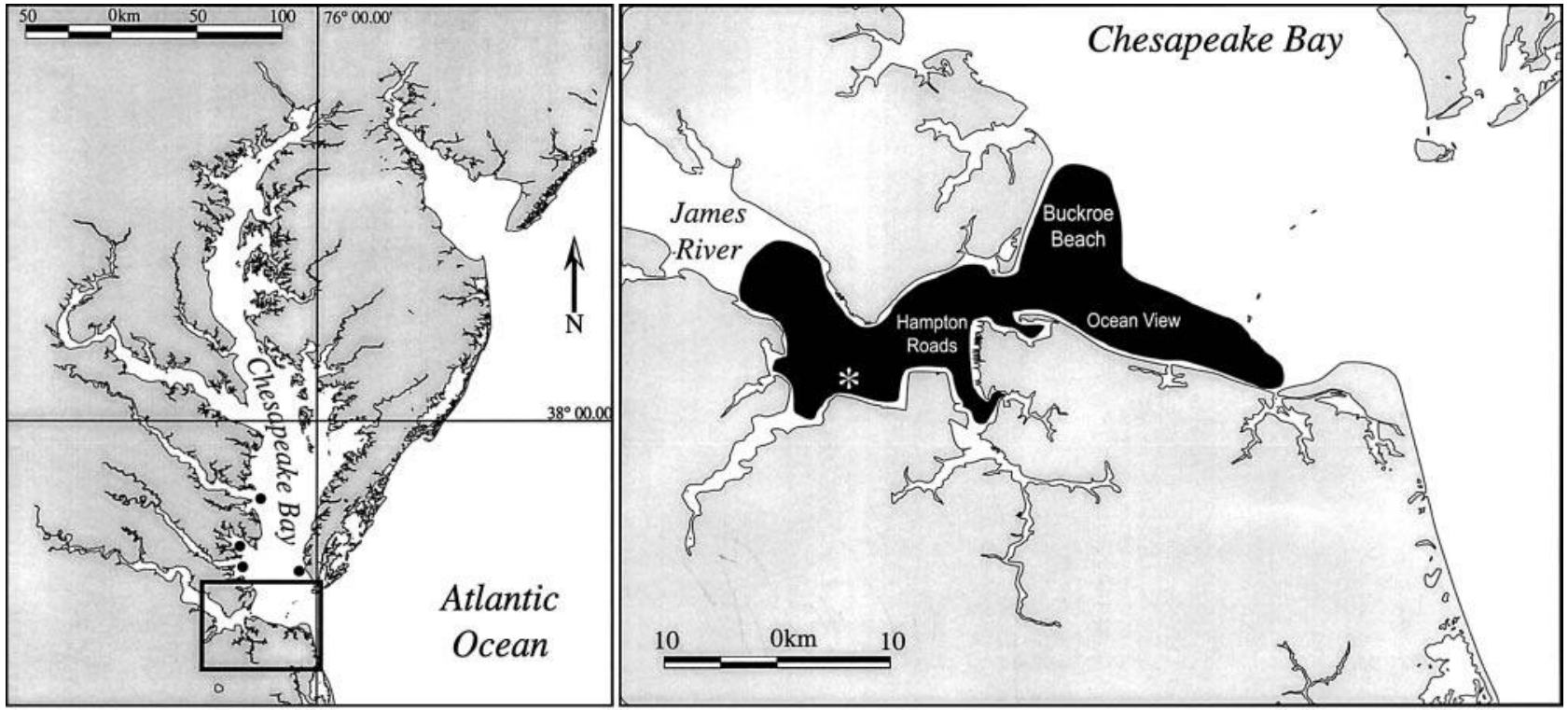

A.

B.

Figure 1. (A) Current distribution of Rapana venosa in the Chesapeake Bay, and (B) distribution of $R$. venosa in the lower James River, Hampton Roads, Buckroe Beach, and Ocean View regions of the Chesapeake Bay. Most collections to date are from these areas (after Harding and Mann, 1999). *marks the site of the first collection in 1998.

subsample was removed and examined under a dissecting microscope to determine both the health of the larvae (as indicated by the percentage of veligers with velum extended and filtering) and their concentration (number $/ \mathrm{ml}$ ). This initial subsample was preserved in $10 \%$ neutral buffered formalin as an index collection for each experiment.

During the summer of 2000, a series of 48-h salinitytolerance experiments at salinities from $7 \mathrm{ppt}$ through $32 \mathrm{ppt}$ were completed using veligers ranging in age from immediately post-hatch (day 0) through the onset of settlement (day 27). The salinity range chosen represents conditions in Chesapeake Bay mainstem areas and tributaries that are potentially most vulnerable to tidal advection of $R$. venosa veligers from downstream sites (see Fig. 2). Each salinitytolerance experiment tested a single age of larvae and incorporated at least three replicates at each of eight salinity levels (e.g., 7, 10, 13, 16, 19, 22, 25, and 32 ppt). Replicates were obtained from larval cultures that originated from different parents. Ages of veligers at the beginning of each experiment are recorded as days post-hatch and include day $0,2,4,6,9,11,13,15,17,19,21,23,25$, and 27. By day 27 , at least $10 \%$ of veliger larvae within experimental cultures were settled, had shed their velum, and were completing metamorphosis to the crawling benthic stage.

Individual boiling tubes were used as experimental chambers and were filled with $20 \mathrm{ml}$ of filtered seawater at 24 to $26{ }^{\circ} \mathrm{C}$. $R$. venosa veligers were added to individual boiling tubes to give densities of at least 1 veliger per milliliter at initial salinities. Salinities within individual tubes were decreased at 5-min intervals by the serial addition of $1 \mathrm{ml}$ of deionized water. Tube 1 (the control tube) received no additions of deionized water and remained at its initial salinity throughout each experiment. During the experiments, larvae were fed $1 \mathrm{ml}$ of Pseudoisochrysis paradoxa, $1 \mathrm{ml}$ of Chaetoceros gracilis, and $0.3 \mathrm{ml}$ of Tetrasalmis sp. per chamber daily. After $44 \mathrm{~h}, 1 \mathrm{ml}$ of concentrated neutral red in filtered seawater solution was added to each experimental chamber. Neutral red is a nontoxic vital stain that is absorbed by living tissue; veligers that were alive at $44 \mathrm{~h}$ absorbed the stain and could then be distinguished from dead veligers by their pink tissue. Experiments were terminated after $48 \mathrm{~h}$ by the addition of $5 \mathrm{ml}$ of $10 \%$ neutral buffered formalin to each tube. Fixed veliger larvae were examined under a dissecting microscope to determine the percentage survival in each chamber after $48 \mathrm{~h}$ exposure to the experimental salinity.

Percentage survival data from all salinity-tolerance experiments satisfied assumptions of homogeneity of variance but failed to meet the assumptions of normality regardless of the transformation (arcsin, square root, $\log _{\mathrm{e}}$, logarithm, reciprocal). A two-factor ANOVA (initial veliger age $\times$ salinity) was used to evaluate percentage survival data. Fisher's multiple comparison test was used for post hoc comparisons when appropriate. All significance levels were established at $P=0.05$ a priori. 


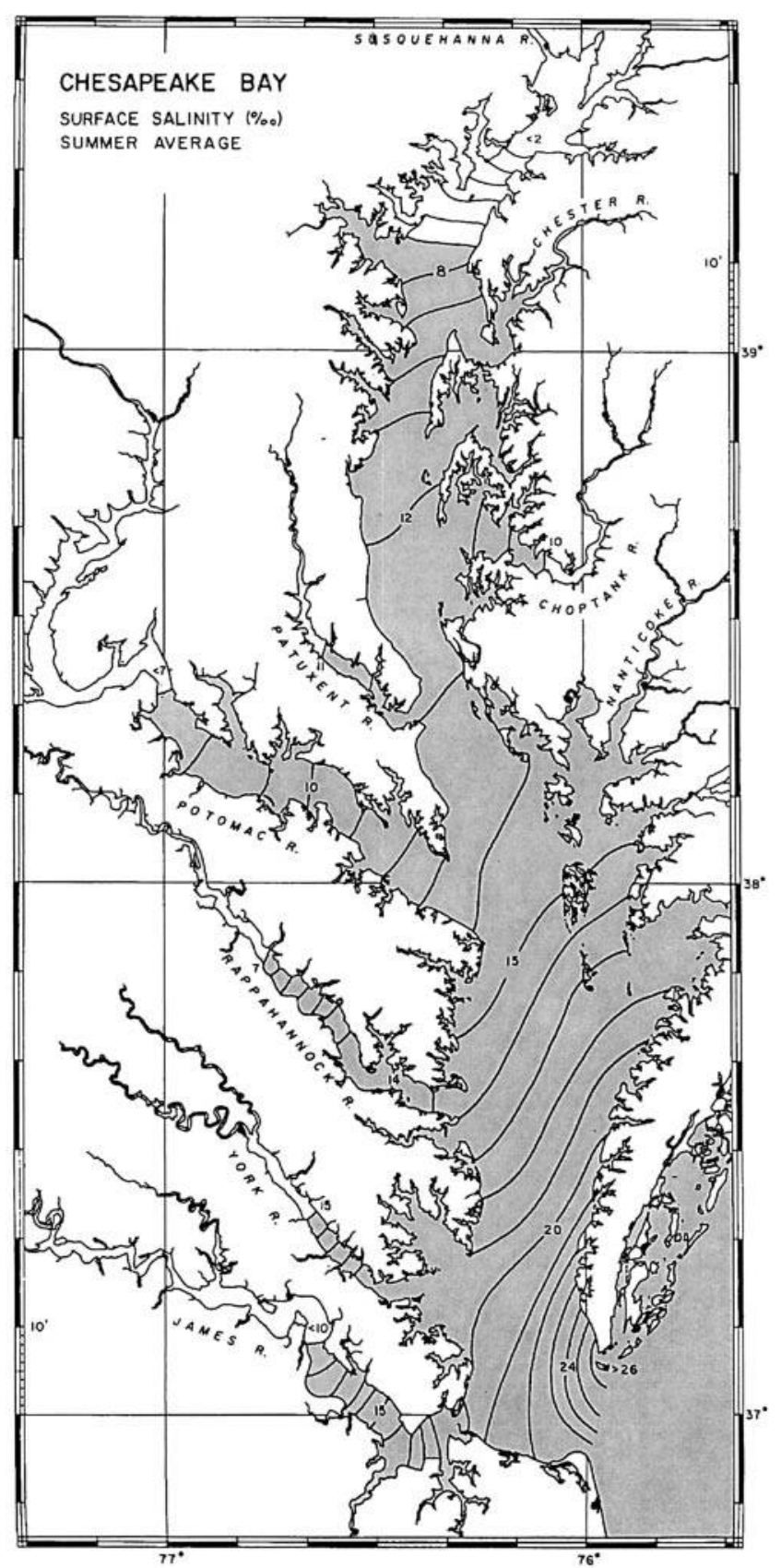

Figure 2. Average summer surface salinity in the Chesapeake Bay (modified from Stroup and Lynn, 1963; data in agreement with Rennie and Neilson, 1994). Shaded regions have salinities suitable for short-term survival of Rapana venosa veligers. Bottom type, availability of suitable prey, and residual circulation to effect larval dispersal support possible establishment within this same region.

\section{Results}

Mean percentage survival of Rapana venosa veligers ranged from $2.3 \%$ at $15 \mathrm{~d}$ and $7 \mathrm{ppt}$ to $100 \%$ at $27 \mathrm{~d}$ and 22 ppt (Table 1). Veliger age and salinity significantly affected the percentage survival (ANOVA, $P<0.001$; Table 2).
There was a significant interaction between veliger age and salinity (ANOVA, $P<0.001$; Table 2). Veligers aged 15 and $17 \mathrm{~d}$ were significantly less tolerant of salinity changes than veligers of all other ages (ANOVA, $P<0.001$; Fisher's test, $P<0.05$ ). Veligers older than $25 \mathrm{~d}$ posthatch had a significantly higher percentage survival than all other ages except $11 \mathrm{~d}$ and $21 \mathrm{~d}$ (ANOVA, $P<0.001$; Fisher's test, $P<0.05$ ). Veligers aged $21 \mathrm{~d}$ had a significantly higher percentage survival than all younger veligers as well as those with an age of $23 \mathrm{~d}$ (ANOVA, $P<0.001$; Fisher's test, $P<0.05)$. Eleven-day-old veligers were significantly more tolerant of salinity changes than were those at ages of $6,9,13,19$, or 23 d (ANOVA, $P<0.001$; Fisher's test, $P<0.05$ ).

Percentage survival of $R$. venosa veligers was significantly less at $7 \mathrm{ppt}$ than at any other salinity (ANOVA, $P<$ 0.001 ; Fisher's test, $P<0.05$ ). There were no differences in percentage survival at salinities greater than $16 \mathrm{ppt}$ (ANOVA, $P<0.001$; Fisher's test, $P<0.05$ ). Percentage survival was significantly lower at $10 \mathrm{ppt}$ than at salinities ranging from 16 to $32 \mathrm{ppt}$ (ANOVA, $P<0.001$; Fisher's test, $P<0.05)$. Percentage survival at 13 ppt was significantly lower than at salinities from 16 to $25 \mathrm{ppt}$ (ANOVA, $P<0.001$; Fisher's test, $P<0.05$ ).

\section{Discussion}

Larvae of Rapana venosa exhibit broad tolerance to salinity as an environmental stressor. With the exception of the combinations of 6-day-old and 13- to 17-day-old veligers at low salinity, all age-salinity combinations in the current study demonstrated substantial survival, in many instances exceeding $90 \%$, over the experimental period. The prospect for larval salinity tolerance to be a limiting factor in further upstream invasion of the Chesapeake Bay from the extant adult population thus appears to be poor. For adults of this species, neither salinity tolerance nor distribution in estuarine systems of graded salinity are well described in the literature for native or invading populations. The current adult population in the Chesapeake Bay (see Fig. 1) rarely experiences bottom salinities below 20 ppt. In the Black Sea, where the annual water temperature range is about $7^{\circ} \mathrm{C}$ to $24^{\circ} \mathrm{C}, R$. venosa occupies a salinity range of 25 to $32 \mathrm{ppt}$ (Golikov, 1967). In the Sea of Azov, which is ice covered for 2 to 4 months of the year, $R$. venosa was restricted to the southernmost region adjoining the Kerch Strait by low persistent salinity in the remaining water body (mean annual value $<12 \mathrm{ppt}$ ). However, a range extension did occur in 1975-1979 when riverine discharge into the Sea of Azov was markedly reduced by water diversion projects (Rubinshtein and Hiznjak, 1988). These projects were discontinued in 1990, and the fresher environment again persists. The current distribution of $R$. venosa in the Sea of Azov with respect to prevailing salinity is 
Table 1

Average percentage survival (standard error in parentheses) for Rapana venosa veligers of various ages ( $0-27$ days post-hatch) exposed to 8 different salinities for $48 h ; \mathrm{n}>20$ veligers per treatment

\begin{tabular}{|c|c|c|c|c|c|c|c|}
\hline \multirow{2}{*}{$\begin{array}{c}\text { Salinity } \\
\text { (ppt) }\end{array}$} & \multicolumn{7}{|c|}{ Veliger age (days post-hatch) } \\
\hline & 0 & 2 & 4 & 6 & 9 & 11 & 13 \\
\hline 7 & $76.9(3.8)$ & $65.5(5.6)$ & $51.0(5.4)$ & $20.5(6.6)$ & $62.3(6.8)$ & $79(12.4)$ & $29.4(8.0)$ \\
\hline 10 & $74.8(5.3)$ & $70.9(5.5)$ & $76.0(3.4)$ & $67.1(4.3)$ & $72.1(5.0)$ & $92.4(1.8)$ & $42.6(2.9)$ \\
\hline 13 & $77.9(2.4)$ & $79.3(2.8)$ & $59.5(6.5)$ & $75.9(9.7)$ & $75.7(6.5)$ & $90.9(3.0)$ & $69.2(2.6)$ \\
\hline 16 & $80.7(2.4)$ & $80.7(3.1)$ & $90.7(3.1)$ & $82.2(3.0)$ & $83.8(3.9)$ & $89.2(1.7)$ & $83.5(2.2)$ \\
\hline 19 & $78.9(3.4)$ & $82.6(3.4)$ & $97.1(0.8)$ & $90.9(2.6)$ & $77.3(3.7)$ & $86.9(5.2)$ & $83.1(3.1)$ \\
\hline 22 & $85.7(3.0)$ & $80.9(5.4)$ & $97.8(1.4)$ & $90.4(2.2)$ & $69.5(3.2)$ & $88.7(2.4)$ & $87.8(1.8)$ \\
\hline 25 & $83.5(6.7)$ & $81.4(2.4)$ & $94.7(2.8)$ & $94.9(0.9)$ & $74.9(7.3)$ & $93.5(1.5)$ & $87.6(1.9)$ \\
\hline \multirow[t]{2}{*}{32} & $59.5(3.8)$ & $90.5(4.1)$ & $89.3(1.4)$ & $97.3(1.4)$ & $79.6(0.9)$ & $85.8(6.5)$ & $84.3(4.1)$ \\
\hline & 15 & 17 & 19 & 21 & 23 & 25 & 27 \\
\hline 7 & $2.3(2.3)$ & $23.3(14.4)$ & $58.4(6.7)$ & $95.8(2.1)$ & $75.9(1.7)$ & $97.2(2.8)$ & $92.5(3.8)$ \\
\hline 10 & $42.5(12.2)$ & $69.4(3.9)$ & $82.2(4.2)$ & $93.3(3.5)$ & $66.4(4.5)$ & $97.0(3.0)$ & $88.7(8.0)$ \\
\hline 13 & $59.9(8.0)$ & $54.6(14.4)$ & $83.0(0.7)$ & $88.9(5.9)$ & $75.0(0.9)$ & $89.9(1.4)$ & $79.5(8.8)$ \\
\hline 16 & $74.3(3.5)$ & $59.7(5.9)$ & $87.0(1.9)$ & $93.9(6.1)$ & $67.7(6.4)$ & $97.2(2.8)$ & $82.6(11.5)$ \\
\hline 19 & $68.8(12.5)$ & $61.4(4.2)$ & $84.1(2.1)$ & $92.0(5.4)$ & $74.8(4.1)$ & $97.4(2.5)$ & $95.2(4.8)$ \\
\hline 22 & $78.8(4.3)$ & $68.8(4.9)$ & $78.7(5.4)$ & $86.1(4.3)$ & $81.0(1.9)$ & $87.1(6.5)$ & $100(0.0)$ \\
\hline 25 & 71.5 (2.6) & $73.0(4.1)$ & $72.7(3.8)$ & $96.7(1.7)$ & $80.9(1.0)$ & $98.0(2.0)$ & $98.7(1.3)$ \\
\hline 32 & $56.3(10.3)$ & $67.6(3.3)$ & $73.7(4.2)$ & $94.5(2.8)$ & $69.9(2.4)$ & $93.7(3.4)$ & $96.4(1.8)$ \\
\hline
\end{tabular}

unclear. The limited observations from the Kerch Strait region suggest that an upstream limit of $12-13$ ppt in the Chesapeake Bay is possible, and that low winter temperatures will not exclude Rapana from regions that infrequently experience winter ice. $\mathrm{Wu}$ (1988) reports that in its native range, $R$. venosa can exploit estuarine regions that have warm summer temperatures and avoid possible surface freezing in winter by migrating into deeper water in these regions.

Larvae of $R$. venosa exhibit considerable plasticity in the duration of their planktonic development under experimental conditions of temperature and salinity that mimic the summer conditions in the Chesapeake Bay, and they do not require specific metamorphic cues to complete the transition to the crawling, benthic post-larval phase (Harding and Mann, unpubl. data). Laboratory-cultured individuals can exploit a variety of native bivalves as prey, including the

Table 2

Summary of two-factor ANOVA (veliger age $\times$ salinity) used to describe salinity tolerances of larval Rapana venosa in laboratory experiments conducted during July 2000

\begin{tabular}{lrcc}
\hline \hline \multicolumn{1}{c}{ Source } & df & $F$-value & $P$-value \\
\hline Veliger age (days post-hatch) & 13 & 31.4 & $<0.001$ \\
Salinity $($ ppt) & 7 & 32.0 & $<0.001$ \\
Veliger age $\times$ salinity & 91 & 4.1 & $<0.001$ \\
\hline
\end{tabular}

hard clam Mercenaria mercenaria (Savini et al., 2003), the oyster Crassostrea virginica, the soft shell clam Mya arenaria, and the mussel Mytilus edulis (Harding and Mann, unpubl. data).

The salinity tolerance of both the larvae and adults of $R$. venosa is greater than that of adults of the genera Busycon and Busycotypus. Thus we predict that in the lower Chesapeake Bay, Rapana will compete directly for space and for prey (notably infaunal pelecypods) with these native species of large predatory gastropods. Indeed, two recent observations indicate that exploitation of this resource by Rapana is increasing.

First, the distinctive boring signature of Rapana (chipping or rasping of the shell margin as described by Morton, 1994) has been seen on specimens of Mercenaria in the lower Chesapeake Bay (Harding, Mann, Kingsley-Smith, and Savini, unpubl. data). Second, studies of the shell morphology of invading Rapana (Green, 2001) point to the same conclusion. Vermeij (1993) examined allometry as a morphological descriptor of shape in gastropods, and noted that high allometric growth rates in gastropods have been correlated with low overall growth rates. Green (2001) demonstrated higher rates of allometric growth in Black Sea populations of $R$. venosa compared to native Korean and Chesapeake Bay populations, which suggests food limitation in the Black Sea location. This finding is consistent with long-term observations of the Black Sea invasion: in its 
initial phase of establishment, Rapana all but eliminated many endemic prey species, resulting in a subsequent phase of very high densities of invaders in intraspecific competition for limited resources of available prey. The suggestion that the Chesapeake Bay populations are not food limited is particularly troubling given the population demographics (see Harding and Mann, 1999, and Mann and Harding, 2000) and the co-location of the invasion with a native hard clam population that supports a local (to the Hampton Roads region of the Chesapeake Bay) fishery with a dock landing value in excess of $\$ 3$ million per year (see Harding and Mann, 1999, fig. 7). Allometric inferences may be challenged where the number of observations is limited; however, one of the strengths of Green's (2001) study is the very large number of observations (Korea, $n=226$; Black Sea, $n=74$; Chesapeake Bay, $n=107$ ) and the range of sizes examined for all geographic populations. Further, the large adult sizes typical of many Chesapeake Bay specimens is unmatched in extant Korean populations, whereas museum collections (U.S. National Museum of Natural History, Smithsonian Institution) of Asian specimens from an era prior to extensive fishing effort match local collections in terms of size. The demographics of the Korean population are indicative of fishing effort on size frequencies that recruit to the fishing gear, whereas that of the Chesapeake Bay population is an ominously threatening indicator of an unexploited stock in the presence of abundant food.

The fact that $R$. venosa combines broad dietary capabilities with broad salinity tolerance suggests that no substantial extant bivalve resources in the lower Chesapeake Bay are in a spatial refuge from predation. The native oyster populations, already depleted by the longterm effects of disease, overfishing, and environmental decline, are included in the susceptible resources. Oyster populations, currently the target of extensive restoration activity (see Luckenbach et al., 1999; Mann, 2000, 2001), are limited to lower salinity sanctuaries from disease in the upper bay and its subestuaries. Although oyster distribution extends into salinities below that tolerated by both larval and adult Rapana (compare distribution data in Kennedy et al., 1996, with Figs. 1 and 2 of this study), significant oyster stocks-which may be disproportionately important as broodstock given their higher salinity locations-are within the salinity tolerance of invading Rapana. The fact that Bombace et al. (1994) observed Rapana in the Adriatic Sea on isolated artificial reef structures similar in concept to those being constructed in the Chesapeake Bay as local foci of increased habitat diversity (see Luckenbach et al., 1999), raises concern for the long-term stability of oyster populations in regions of restored habitat within the bay.

The combination of pelagic larval dispersal and broad salinity tolerance in $R$. venosa potentially complicates the ability of the native oyster drill, Urosalpinx cinerea, to re-establish its former range within the Chesapeake Bay. Urosalpinx populations were once extensive and abundant within the bay, but the freshets associated with Hurricane Agnes in 1972 decimated these populations. Post-Agnes survival was limited to a region near the Bay mouthessentially all oyster beds in the subestuaries of the Bay were purged of Urosalpinx by this single event. Unlike Rapana, Urosalpinx has no pelagic larval stage. Juveniles of Urosalpinx hatch and crawl away from the substrate-attached egg masses. Urosalpinx has been recolonizing its former Bay habitat over the past three decades by crawling up the Bay bottom over "islands" of suitable substrate. In the absence of an invader, the temporary displacement of Urosalpinx is but a minor perturbation in evolutionary time; however, the introduction of Rapana adds a new and opportunistic component to this reestablishment process. There arguably now exists a race to reoccupy this temporarily vacated niche; a race that may favor the invader because of the sequence of events that temporarily displaced the native species.

Vermeij (1996) theorized that physiological tolerances are evolutionarily conservative parameters contributing to the determination of the range of survival. In this context we predict that, as a result of the counterclockwise, gyre-like circulation within the Chesapeake Bay, pelagic larvae of Rapana venosa originating from parents in the Hampton Roads region will initially be distributed northward along the western shore of the DelMarVa peninsula, and will eventually reach the lower sections of all the major subestuaries of the western shore of the Bay. This entire region is within the salinity tolerance of the larval forms (compare Table 1 with Fig. 2). The potential for long-distance dispersal within a single generation remains to be determined, although recent collections of small ( $<75 \mathrm{~mm}$ in length) adults on the Virginia Bay shore of the peninsula suggest that a distance of tens of kilometers per generation is possible. Dispersal onto and along the coastal shelf outside of the Bay mouth may be influenced by both northward- and southward-flowing residual current. The effects on dispersal depend on depth, wind conditions, and time within the known egg laying period of the invader in the southern Chesapeake Bay. Establishment over a period of decades by natural dispersal in estuaries and coastal regions from Cape Cod to Cape Hatteras was considered a high probability by Mann and Harding (2000). This prediction still stands and is supported by the essentially continuous distribution of mollusc species suitable as prey in shallow waters throughout this range (for examples, see Theroux and Wigley, 1983). The time frame may, however, be considerably reduced by dispersal of larval forms in ballast water during intra-coastal maritime trade, a suggestion reinforced by the tolerance of the larval form (this study) and the location of both the Norfolk, Virginia, U.S. Naval base and an international 
container terminal within the extant adult range of invasion in Hampton Roads. If, as Vermeij (1996) suggests, factors such as "the presence of competitors, predators, or disease organisms, or the absence of a critical host, food, or symbiotic species" prevent a species from extending its range, it is unlikely that Rapana will be further restricted within the projected range. Large individuals of $R$. venosa appear admirably equipped to compete with large native gastropods and have few obvious predators in the Middle Atlantic coastal region when they are full grown. We can find no reports of diseases of $R$. venosa in any of its native or introduced ranges. Finally, the only notable parasite of $R$. venosa in both its Black Sea and Chesapeake Bay populations are shell-boring polychaetes of the genus Polydora (Gutu and Marinescu, 1979; Mann and Harding, 2000). The actions of Polydora appear to have little, if any, detrimental effect on infected individuals in either location; may be limited to some individuals of $R$. venosa that forage epifaunally; and may be terminated by burial of the host whelks as they grow and shift to an infaunal habit. Indeed, observations on rapa whelk biology and physiological tolerances in the Chesapeake Bay strongly suggest that this animal is capable of successful colonization and establishment of viable populations within estuarine habitats up and down the East Coast of the United States.

\section{Acknowledgments}

Support for this project was provided by Virginia Sea Grant (R/MG-98-3), the Department of Fisheries Science, Virginia Institute of Marine Science, and partial support to RM by the National Science Foundation (OCE-9810624). Special thanks are extended to local watermen and seafood processors who donated adult Rapana to our research collection. We thank D. Bryn Jones, Dario Savini, Melissa Southworth, Rhonda Howlett, Peter Kingsley-Smith, Erica Westcott, Stephanie Haywood, and Catherine Ware for assistance in maintenance of adult brood stock and larval cultures. This manuscript is dedicated to the late Professor Ruth Dixon Turner, whose enthusiasm for the larval ecology of marine molluscs remains as an inspiration to us all. This is Contribution Number 2506 from the Virginia Institute of Marine Science.

\section{Literature Cited}

Bombace, G., G. Fabi, L. Fiorentini, and S. Speranza. 1994. Analysis of the efficacy of artificial reefs located in five different areas of the Adriatic Sea. Fifth International Conference on Aquatic Habitat Enhancement. Bull. Mar. Sci. 55(2-3): 559-580.

Carlton, J. 1996. Pattern, process, and prediction in marine invasion ecology. Biol. Conserv. 78: 97-106.

Carlton, J. 1999. Molluscan invasions in marine and estuarine communities. Malacologia 41: 439-454.

Chukchin, V. 1984. Ecology of the Gastropod Molluscs of the Black Sea. Acad. Sc. USSR, Naukova Dumka, Kiev. 175 pp. (in Russian).
Chung, E.Y, S. Y. Kim, and Y. G. Kim. 1993. Reproductive ecology of the purple shell, Rapana venosa (Gastropoda: Muricidae), with special reference to the reproductive cycle, deposition of egg capsules and hatching of larvae. Korean J. Malacol. 9(2): 1-15.

Cucaz, M. 1983. Rapana venosa (Valenciennes, 1846) vivente nel Golfo di Trieste. Boll. Malacol. 19(9-12): 261-262.

Drapkin, E. 1963. Effect of Rapana bezoar Linne (Mollusca, Muricidae) on the Black Sea fauna. Dokl. Akad. Nauk. SSSR. 151: 700-703.

Ghisotti, F. 1971. Rapana thomasiana Crosse, 1861 (Gastropoda, Muricidae) nel Mar Nero. Conchiglie (Milan) 7: 55-58.

Ghisotti, F. 1974. Rapana venosa (Valenciennes), nuova ospite Adriatica? Conchiglie (Milan) 10: 125-126.

Golikov, A. N. 1967. Gastropoda: Pp. 79-91 in Animals and Plants of Peter the Great Bay. Nauka, Leningrad.

Green, R. 2001. Morphological variation of three populations of the veined rapa whelk, Rapana venosa, an invasive predatory gastropod species. Master's thesis, College of William and Mary, Gloucester Point, VA.

Gutu, M., and A. Marinescu. 1979. Polydora ciliata Polychaeta perforates the gastropod Rapana thomasiana of the Black Sea. Trav. Mus. Hist. Nat. "Grigore Antipa" 20: 35-42.

Hanna, G. D. 1966. The introduced mollusks of Western North America Occas. Pap. Calif. Acad. Sci. Vol. 48. 108 pp.

Harding, J. M., and R. Mann. 1999. Observations on the biology of the veined rapa whelk, Rapana venosa (Valenciennes, 1846) in the Chesapeake Bay. J. Shellfish Res. 18: 9-17.

Hutchinson, G. E. 1979. An Introduction to Population Ecology. Yale University Press, New Haven, CT.

Kennedy, V. S., R. I. E. Newell, and A. F. Eble, eds. 1996. The Eastern Oyster, Crassostrea virginica. University of Maryland Sea Grant Press, College Park, MD. 734 pp.

Kool, S. 1993. Phylogenetic analysis of the Rapaninae (Neogastropoda: Muricidae). Malacologia 35: 155-259.

Koutsoubas, D., and E. Voultsiadou-Koukoura. 1990. The occurrence of Rapana venosa (Valenciennes, 1846) (Gastropoda, Thaididae) in the Aegean Sea. Boll. Malacol. 26(10-12): 201-204.

Lai, K. Y., and C. W. Pan. 1980. The Rapana shells of Taiwan. Bull. of Malacology, Republic of China. 7: 27-32.

Luckenbach, M., R. Mann, and J. E. Wesson, eds. 1999. Oyster Reef Habitat Restoration: A Synopsis of Approaches. Virginia Institute of Marine Science, Gloucester Point, VA. 366 pp.

Mann, R. 2000. Restoring oyster reef communities in the Chesapeake Bay: a commentary. J. Shellfish Res. 19: 335-340.

Mann, R. 2001. Restoration of the oyster resource in the Chesapeake Bay. Bull. Aquacul. Assoc. Can. 101: 38-42.

Mann, R., and J. M. Harding. 2000. Invasion of the North American Atlantic coast by a large predatory Asian mollusc. Biol. Invasions 2: $7-22$.

Marinov, T. M. 1990. The Zoobenthos From the Bulgarian Sector of the Black Sea. Academy of Science Publications Sofia. 195 pp. [In Bulgarian].

Mel, P. 1976. Sulla presenza di Rapana venosa (Valenciennes) e di Charonia variegata sequenzae (Ar. \& Ben.) nell'Alto Adriatico. Conchiglie, (Milan) 12(5-6): 129-132.

Morton, B. 1994. Prey preference and method of attack by Rapana bezoar (Gastropoda: Muricidae) from Hong Kong. Pp. 309-325 in The Malacofauna of Hong Kong and Southern China III, B. Morton, ed. Hong Kong University Press, Hong Kong.

Pastorino, G. P., A. Penchaszadeh, L. Schejter, and C. Bremec. 2000. Rapana venosa (Valenciennes) (Mollusca: Muricidae): a new gastropod in South Atlantic waters. J. Shellfish Res. 19: 897-900.

Rennie, S., and B. Nielson. 1994. Chesapeake Bay Atlas. Virginia Institute of Marine Science, Gloucester Point, VA. 
Rinaldi, E., 1985. Rapana venosa (Valenciennes) spiaggiata in notevole quantita sufla spiaggia di Rimini (Fo). Boll. Malacol. 21: 318.

Rubinshtein, I. G., and V. I. Hiznjak. 1998. Stocks of Rapana thomasiana in the Kerch Strait. Rybn. Khoz 1: 39-41 (in Russian).

Sandlund, O. T., P. J. Schei, and A. Viken. 1999. Introduction: the many aspects of the invasive alien species problem. Pp. 1-7 in Invasive Species and Biodiversity Management, O. T. Sandlund, P. J. Schei, and A. Viken, eds. Kluwer Academic Publishers, Dordrecht. 413 pp.

Savini, D., J. M. Harding, and R. Mann. 2003. Rapa whelk Rapana venosa (Valenciennes, 1846) predation rates on hard clams Mercenaria mercenaria (Linneaus, 1758). J. Shellfish Res. 21(2). (In press).

Stroup, E., and R. Lynn. 1963. Atlas of Salinity and Temperature Distributions in Chesapeake Bay 1952-61 and Seasonal Averages 1949-61. Graphical Summary Report 2. Report 63-1. The Chesapeake Bay Institute, The Johns Hopkins University.

Terreni, G. 1980. Molluschi poco conosciuti dell'Arcipelago Toscano: 1-Gasteropodi. Boll. Malacol. 16: 9-17.
Theroux, R. B., and R. L. Wigley. 1983. Distribution and Abundance of East Coast Bivalve Mollusks Based on Specimens in the National Marine Fisheries Service Woods Hole Collections. NOAA Technical Report NMFS SSRF-768. 172 pp.

Tsi, C. Y., X. T. Ma, Z. K. Lou, and F. S. Zhang. 1983. Illustrations of the Fauna of China (Mollusca), Vol. 2, plates I-IV. Science Press, Beijing. $150 \mathrm{pp}$.

Vermeij, G. J. 1993. A Natural History of Shells. Princeton University Press, Princeton, NJ.

Vermeij, G. J. 1996. An agenda for invasion biology. Biol. Conserv. 78: 3-9.

Williamson, M. 1996. Biological Invasions. Chapman and Hall, London. 244 pp.

Wu, Y. 1988. Distribution and shell height-weight relation of Rapana venosa Valenciennes in the Laizhou Bay. Marine Science/Haiyang Кехие 6: 39-40.

Zolotarev, V. 1996. The Black Sea ecosystem changes related to the introduction of new mollusc species. Mar. Ecol. 17: 227-236. 